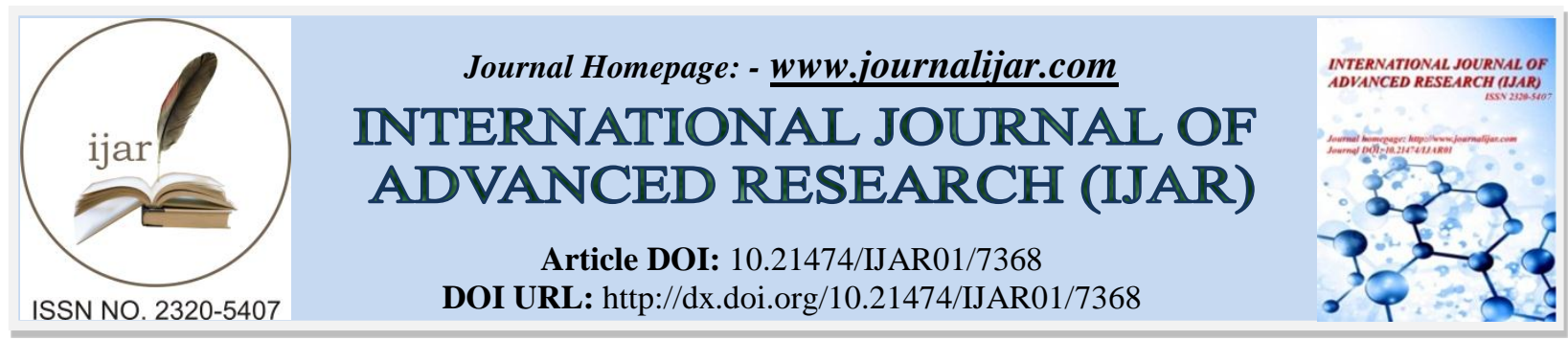

RESEARCH ARTICLE

\title{
THE STATE RESPONSIBILITY FOR THE ENVIRONMENTAL DAMAGE OF MOUNT BAWAKARAENG.
}

Alfian, Muhammad Yunus and Irwansyah.

Faculty of Law Hasanuddin University, Indonesia.

\section{Manuscript Info}

Manuscript History

Received: 08 May 2018

Final Accepted: 10 June 2018

Published: July 2018

Keywords:-

Damage, Gunung Bawakaraeng, and

State Responsibility.

\begin{abstract}
This study aims to determine responsibility of the State against the Damage of the Environment at Mount Bawakaraeng and also to know the prevention efforts Damage Environment at Mount Bawakaraeng Area. This research was conducted in Gowa Regency and Makassar City of South Sulawesi. The research method used empiricalnormative method, it is intended that the authors describe the overall data obtained through interview, literature study, and observation result. The results are then analyzed and associated with the formulation of legislation and taken conclusions or answers to answer the problems examined by the author. The results of this study indicate that the Ministry of Environment and Forestry with the obligations attached to it in managing the forest in this area of Mount Bawakaraeng still can not be categorized as running maximally, either coordination of related institutions and handling in providing responsibility to Damage Environment Living on Mount Bawakaraeng.
\end{abstract}

Copy Right, IJAR, 2018,. All rights reserved.

\section{Introduction:-}

Environmental laws include pollutant regulations and the conservation of natural resource allocations. This concerns the energy, agriculture, real estate, and land use, and has expanded to be included in international environmental governance, international trade, environmental justice, sustainable growth and development, food law, and climate change. Environmental law is a broader category that incorporates both resource laws and pollution control laws, which regulate the impact of the human environment. ${ }^{1}$

The principle of public participation in the international legal environment can be traced to the 1992 Rio Declaration and Agenda 21. According to Agenda 21,

One of the fundamental prerequisites for the achievement of sustainable development is broad public participation in decisionmaking. Furthermore, in the more specific context of environment and development, the need for new

${ }^{1}$ Career Development Office of Yale Law School. 2017. Environmental Law. Yale Law School Nondiscrimination Policy, (Online), p. 5 (accessed January $1^{\text {st }} 2018$ ).

${ }^{2}$ U.N. Doc. A/CONF.151/26 (Vol. III), United Nations Conference on Environment and Development, Rio de Janeiro, Braz., June 3-14, 1992, Agenda 21, 23.2, (Aug.14, 1992), available at http://www.un.org/esa/dsd/agenda21/res_agenda21_23.shtml.,_accessed January $1^{\text {st }} 2018$ at $05.00 \mathrm{pm}$.

Corresponding Author:- Alfian.

Address:- Faculty of Law Hasanuddin University, Indonesia. 
forms of participation has emerged. This includes the need of individuals, groups and organizations to participate in environmental impact assessment. they live and work.

Based on the fragmented Agenda 21 above, one of the fundamental prerequisites for the achievement of sustainable development is the participation of the community in decision-making. At the national level, each individual is entitled to access information relating to the environment held by the public authorities and the opportunity to participate in the decision making process Country mustfacilitate and encourage public awareness and participation by providing information widely.

International environmental law is a field that has significant success in history. Continuing international evolution, environmental law is vital for global efforts to identify and respond to problems. Even when faced with less complex dilemmas, however, international environmental law is part of not just a portion of the solution. International environmental law has limits. According to the Secretary-General of the United Nations, Ban Ki Moon,

\section{"Law affects the future of humanity, and. . the future of the planet " 4}

Based on the above quotation it can be concluded that international environmental law is very influential on global issues in the future.

Indonesia's Environmental Protection And Management (PPLH) has a fundamental position in Indonesian legislation. This affirmation lays down the "State Obligations" and "Government Duties" to protect all Indonesian human resources (as a component of human resources) and the entire Indonesian blood spill as a component of biological resources and non-biological natural resources (abiotic) components for the happiness of all Indonesians and all mankind. ${ }^{5}$

As one of the countries that is claimed to be the lungs of the world, Indonesia has the largest tropical rain forest to the 3rd in the world, after Brazil and Congo, about 99, 6 million hectares of forest area in Indonesia. ${ }^{6}$ Given Indonesia's vast natural wealth, it is certainly not an easy task in protecting and managing the environment, in accordance with the results of the United Nations Conference on Environment held in Stockholm in 1972 and a Declaration on the Environment of the Earth Summit in Rio de Janeiro Year 1992 which agreed on the principle of development decision-making should take account of the environmental and human dimensions and the Sustainable Development Summit in Johannesburg in 2002 which addresses and mitigates the deterioration of environmental quality.

Awareness of a healthy environment is still very minimal, both the awareness of society and the role of government in creating a healthy environment, as one example; Mount Bawakaraeng, an ecologically important water catchment area of this mountain has an important position as a source of water storage that includes at least five administrative areas namely: Makassar, Gowa, Bantaeng, Bulukumba and Sinjai, South Sulawesi. Biological richness which later became the source of life of the surrounding community and the inherent cultural values are very strong in the area of Mount Bawakaraeng provide its own charm to tourists, nature lovers and academics/ researchers. However, the current condition of Mount Bawakaraeng is very concerning, filled with a lot of garbage, proven in some climbing post formed garbage hills, even some climbers who hung their garbage among the trees, not only garbage, another factors causing damage to Mount Bawakaraeng are the fallen tree, forest burning and possibly felled only to open the path for climbers, The condition of the trees that once shade is now thinning.

${ }^{3}$ U.N. Doc. A/CONF.151/26 (Vol. I), United Nations Conference on Environment and Development, Rio de Janeiro, Braz., June 3-14, 1992, Rio Declaration on Environment and Development, 10, (Aug. 12, 1992) [hereinafter Rio Declaration], available at http://www.un.org/documents/ga/conf151/aconf15126-1annex1.htm., accessed January $1^{\text {st }} 2018$, at $07.00 \mathrm{pm}$.

${ }^{4}$ Cinnamon, Carlarne. 2014. Delinking International Environmental Law \& Climate Change. Michigan Journal of Environmental \& Administrative Law, Volume 4 (Online), Issue 1 (accessed January $1^{\text {st }} 2018$ )

${ }_{6}^{5}$ Yunus Wahid. 2014. Pengantar Hukum Lingkungan, Makassar: Arus Timur. p. 183

6 WWF, "Deforestasi", http://menulis-makalah.blogspot.co.id/2015/06/cara-menulis-footnote-catatan-kakiyang.html, accessed December $4^{\text {th }} 2017$ at 02.51 am 
Thus, looking at the problem is quite complex in Indonesia in general and in the area of Mount Bawakaraeng in particular, it is very urgent to be able to do protection and environmental management is good and right.

\section{Research Questions:-}

In connection with the background of such thoughts, it can be identified the main issues to be discussed, are as follows:

1. What is the form of State responsibility for Environmental Damage in Mount Bawakaraeng?

2. How is Environmental Damage prevention efforts in Mount Bawakaraeng Area?

\section{Research Methods:-}

In conducting research in the field, the authors choose the location of research in Gowa Regency and Makassar City of South Sulawesi, with object and research subjects in Bawakaraeng Mountain Area, Site selection is based on the consideration that in the place will be obtained data related to scientific studies. Determination of this location is expected to provide significant data in accordance with the title and problems in this study.

The type of research used by the author is the normative empirical research. Peter Mahmud Marzuki explains that normative legal research is a process to find a rule of law, legal principles, and legal doctrines to answer the legal problems faced. ${ }^{7}$ While empirical research is a research conducted directly from the community as the first source through field research, empirical legal research provides an important meaning to the analysis that is quantitative and empirical, so that the steps and technical design of the research follow the pattern and research of social science, especially sociological science (socio-legal research). ${ }^{8}$

Furthermore, the type of normative legal research is conducted by collecting legal materials both primary, secondary and/or tertiary. In order to obtain an answer or solution to environmental pollution problems in the Bawakaraeng Mountains area of Gowa Regency of South Sulawesi Province and will be correlated with a juridical analysis approach to national environmental law by looking at the culture of the local culture.

Soerjono Soekanto argues that normative and empirical legal research can be carried out separately or in combination, ${ }^{9}$ therefore the writer took the initiative to combine this research intonormative emp iris research in order to enrich the li terasi jurisprudence through multi methods.

\section{Results And Discussion:-}

Regulations Relating to State Responsibility:-

Conceptually, according Soerjono Soekanto in Irwansyah ${ }^{10}$ that the core and meaning of law enforcement lies in the activities of harmonizing the value relationships laid out in steadfast rules and acts as a series of final value stages, to create, maintain and maintain the peace of life within society.

The responsibility of the state is a fundamental principle in international law that comes from the doctrine of international legal experts. The responsibility of the State arises when there is a breach of an international obligation to do something, whether such obligations under international treaties or by international custom. Black's Law Dictionary there is only a narrow sense of responsibility that is answerability or accountability . ${ }^{11}$ In this regard, in particular within the scope of our own Environmental Law, we can refer to the Stockholm Declaration of 1972, essentially formulated as a duty to protect the environment, not only the environment within the national territory, but also the global environment. The Principle 21 of the Stockholm Declaration of 1972 sets forth: ".... the responsibility to ensure that activities within their jurisdiction or control do not cause Damage to the environment of States or of areas beyond the limits of national jurisdiction. "The principle is intended as a preventive measure damage or pollution of the environment within the territory and is cross border. Twenty years later the Rio de Janeiro Declaration was born, still the same as the previous declaration of the declaration in "Rio" also discusses Environmental Degradation but focuses more on issues of pollution, climate change, ozone depletion, use and

\footnotetext{
${ }^{7}$ Peter Mahmud Marzuki. 2009, Penelitian Hukum, Jakarta: Kencana Prenada Media Group, p. 35.

${ }^{8}$ Ibid.

${ }^{9}$ Soerjono Soekanto dan Sri Mamudji, 2001, Penelitian Hukum Normatif; Suatu Tinjauan Singkat, Jakarta: Raja Grafindo Persada, p. 1-2.

${ }^{10}$ Irwansyah, 2013, Aspek Hukum Audit Lingkungan, Jakarta: YAPMA, p. 91

${ }^{11}$ Bryan A. Garner, 2014, Black's Law Dictionary Tenth edition, Claitors Pub Division, New York, p. 211.
} 
management of marine and water resources, the escalation of deforestation, land degradation and degradation, hazardous wastes and biodiversity depletion. But basically the Environmental Law includes the structuring and enforcement or compliance and enforcement. ${ }^{12}$

\section{Forest Area Function Management:-}

Article 12 of Law no. 41 of 1999 on Forestry explains that forestry planning activities include forest inventory, forest area establishment, forest area stewardship, establishment of forest management areas, and forestry plan preparation, in Law no. 23 of 2014 on Regional Government, all forestry planning affairs become the authority of the Central Government. This law does not provide authority of forestry planning explicitly for provinces and districts / municipalities.

Observing the above, the authority of the Provincial Region in forestry planning is limited to assisting forestry planning. The forms can be proposed technical considerations of forestry planning, for example: proposed changes in status and function of the region, determination of Forest Management Unit (KPH), and so on. Article 21 of Law no. 41 of 1999 on Forestry explains that forest management activities include :

1. Forest governance and forest management planning.

2. Forest utilization and use of forest area.

3. Forest rehabilitation and reclamation.

4. Forest protection and nature conservation.

Law no. 23 of 2014 on Regional Government eliminates the authority of forest management at the district level City. According to this Law, the authority of forest management is shared between the Central and Provincial Governments. Central Government authorities in forest management include:

1. Implementation of forest governance.

2. Implementation of forest management plan.

3. Implementation of forest utilization and use of forest area.

4. Implementation of forest rehabilitation and reclamation.

5. Implementation of forest protection.

6. Implementation of processing and administration of forest products.

7. Implementation of Forest Area Management with Special Purpose (KHDTK).

While the authority of Provincial Government in natural forest management are:

1. Implementation of forest regulation on Forest Management Unit (KPH), except in KPH Conservation (KPHK).

2. Implementation of KPH management plan, except for KPHK.

3. Implementation of forest utilization in production forest and protection forest areas, including:

4. Utilization of forest area.

5. Utilization of non-timber forest products.

6. Collection of forest products

7. Utilization of environmental services, except for the utilization of carbon storage and/or absorption.

8. Implementation of rehabilitation outside State forest area.

9. Implementation of forest protection in protected forests and production forests.

10. Implementation of non-timber forest product processing.

11. Implementation of wood forest product processing with production capacity $<6000 \mathrm{~m} /$ year.

12. Implementation of KHDTK management for religious purposes.

Based on the description of the above mentioned forest management authority, it is understood that the current strategic policy in forest management is the development of KPH. KPH is designed to strengthen local participation in proposed forest area utilization and management. Therefore, forestry planning at the micro level will be mostly done by KPH. The role of the Provincial Region in this case is very strategic to determine the forest management plan.

The licensing authority is part of forest management, where the strategic licensing authority (landscape change) is still in the hands of the Central Government, the Ministry of Environment and Forestry (KLHK). Whereas other

\footnotetext{
12 Syahrul Mahfud. 2012. Penegakan Hukum Lingkungan Indonesia, second edition cet. Pertama. Yogyakarta:
} Graha Ilmu, p. 3. 
permits that do not change the landscape become the authority of the Provincial Government. Such licensing basically still follows the previous rules which give most of the licensing authority to the Central Government, Provincial Region and District / City, as described in:

1. PP no. 6 Year 2007 Jo PP No. 3 of 2008 on forest governance and forest management planning and forest utilization.

2. PP no. 10 Year 2010 Jo PP No. 60 Year 2012 on the procedures for zoning changes and function of the area.

3. PP no. 24 Year 2010 Jo PP No. 105 of 2015 on the use of forest areas.

Government Regulation no. 28 Year 2011 on the Management of Nature Reserve and Nature Conservation Area, Forest Park (Tahura) is a conservation area for the purpose of collecting plants and/or animals that are natural and non-natural, genuine and non-invasive, non-invasive species and used for research purposes, science, education, cultivation support, tourism and recreation.

Tahura can be utilized for activities:

1. Research and development of science and technology,

2. Education and awareness of conservation awareness,

3. Collection of biodiversity riches,

4. Carbon storage and / or absorption, water use and water, heat and wind energy and nature tourism,

5. Utilization of plants and wildlife in order to support the cultivation in the form of provision of germplasm,

6. Traditional use by local communities, in the form of non-timber forest product collection, traditional cultivation, and traditional hunting are limited to unprotected species,

7. Fostering populations through breeding in order to breed animals or artificially propagating plants in seminatural environments.

In Law no. 23 of 2014 on Regional Government, one of the sub-affairs of the conservation areas whose management is handed over to the Regency / Municipality is the management of Tahura. The management of Tahura which is the authority of the Regency / Municipality is Tahura whose entire forest area is within the administrative area of the Regency / City. While the Tahura area of forest area cross District / City, forest management authority becomes the authority of the Provincial Government. The management of Tahura shall be carried out by a management unit established by the Governor or Regent / Mayor based on the criteria established by the Minister of Environment and Forestry. Manager of tahura in the form of Technical Implementation Unit from local government.

Based on the above description, it is clear that the authority of forest management today is mostly located in the Central Government. At the regional level, authorities in the implementation of forest area planning and utilization and some non-timber licensing are submitted to Provincial Areas. While Regency / City is given a limited portion of authority in managing the implementation of KPH as a forwarding authority of the Provincial Region at the Regency / City level. The management of Tahura shall be submitted to the Regency / City Government but on a limited utilization scale in accordance with the Norms, Standards, Procedures and Criteria established by the Central Government.

The scheme of environmental management institutions Under the Law of Environmental Management and Protecting (UUPPLH) is that sectoral ministries such as the Ministry of Industry, Ministry of Forestry, Ministry of Mineral Resources, Ministry of Agriculture and others still have the authority of environmental management within the limits of their authority as defined in their sectoral laws, while the Ministry of the environment performs coordination tasks in addition to the tasks of implementing environmental management within the limits stipulated in the UUPPLH. ${ }^{13}$ Thus, the enforcement of environmental law is an attempt to achieve compliance with rules and requirements in general and individual legal provisions through the supervision and application (or threat) of administrative, criminal, and civic facilities. ${ }^{14}$

\section{Environmental Damage Prevention at Mount Bawakaraeng Area:-}

Geographically the area of Mount Bawakaraeng is at $119^{\circ} 56^{\prime} 40$ " East Longitude; and $05^{\circ} 19$ '01" South Latitude, while the geological geology of this mountainous region originated from the formation of Lompobattang volcanic

${ }^{13}$ Rahmadi, Takdir. 2016. Hukum Lingkungan di Indonesia. Jakarta: PT. Rajagrafindo Persada. p. 64.

${ }^{14}$ Erwin, Muhammad. 2015. Hukum Lingkungan Dalam Sistem Perlindungan dan Pengelolaan Lingkungan Hidup di Indonesia. Bandung: PT. Refika Aditama. p. 159 
volcano which erupted and then formed a number of craters (now better known as the Ramma Valley, Lowe Valley and Anjayya Valley) appointment (Mount Bawakaraeng) and forming the unity of Lompobattang mountain range.

Mount Bawakaraeng, is a water catchment area that ecologically this mountain has an important position because it becomes a source of water storage which includes at least five administrative areas in South Sulawesi Province, namely: Makassar City, Gowa Regency, Bantaeng Regency, Bulukumba Regency and Sinjai Regency. Biological richness which later became the source of life of the surrounding community and the inherent cultural values are very strong in the area of Mount Bawakaraeng provide its own charm to tourists, nature lovers and academics / researchers. However, the current condition of Mount Bawakaraeng is very concerning, filled with a lot of garbage, proven in some climbing post formed garbage hills, even some climbers who hung their garbage among the trees, not only garbage, other factors cause damage to Mount Bawakaraeng are fallen trees, forest burning and possibly felled only to open the path for climbers, The condition of the trees that once shade is now thinning.

Adi Tonggiroh from the Institute of Research and Community Service (LPPM) Hasanuddin University, describes the condition of the mountain is influenced by natural factors and human factors themselves. According to him, the human factor is more vulnerable to causing damage than natural factors because human footing in rocks will change the structure of the rocks while the rocks are temperature sensitive. ${ }^{15}$ The condition of the destruction of Mount Bawakaraeng is also marked by the broken Mount Sorongan which is one of the mountain children who are in the Bawakaraeng Mountains area. Prof. Dorothea Agnes Rampisela ${ }^{16}$ said that the result of the fault, the Watershed (DAS) also experienced sedimentation. Mountain climate provides a unique and important perspective to approach climate change issues for various reasons. First, the mountain is an essential element of natural ecosystems. Secondly, the mountain and their human community are highly vulnerable to the effects of climate change. ${ }^{17}$

Mountains are an early indicator of climate change because vegetation, hydrology, and climate vary greatly with altitudes above a relatively short horizontal distance, creating high biodiversity and rapid changes in plant and animal life. ${ }^{18}$

The role of the Directorate General of Watershed Management and Protected Forest is sufficient to protect the function of protected forest areas located in Gunung Bawakaraeng Area in particular and in Indonesia in general, but the reality is always not directly proportional to what we expect, that the facts such areas as Protected Forest Area, Limited Production Forest Area, Permanent Production Forest Area and Nature Conservation Area / Natural Conservation Area are still getting damage or Damage, pollution of organic / non-organic waste, land clearing, area open vegetation cover, until the upstream sedimentation of the rivers jeneberang is increasing.

\section{Conclusion:-}

Based on the results of research and discussion, the conclusions that can draw writer is as follows, Form of Responsibility State is the responsibility that must be obtained by every citizen given by the Government in this case related to the Environment in accordance with what is implied by Article $28 \mathrm{H}$, The Constitution of the State of the Republic of Indonesia 1945. The Ministry of Environment and Forestry with the obligations attached to it in managing forests in this area of Mount Bawakaraeng still can not be categorized as running maximally, as well as the Provincial Government and Regency Government that can not participate maximally either coordination of related institutions or handling in giving accountability to Damage of Environment at Mount Bawakaraeng.

\footnotetext{
${ }^{15}$ Eksepsi Online, "Gununung Bawakaraeng Mengalami Kerusakan", http://eksepsionline.com/2017/05/09/gunungbawakaraeng-mengalami-kerusakan/, accessed October 14th 2017 at $05.10 \mathrm{pm}$

${ }^{16}$ Professor of Agrotechnology Studies Program, Faculty of Agriculture, Hasanuddin University

${ }^{17}$ Akin, Jena. 2012. Civil Justice in the Mountains: The Bolivian Andes as Grounds for Climate Reform. Colorado Journal of International Environmental Law and Policy, Volume 23(Online), Number 2 (accessed January $1^{\text {st }} 2018$ ) ${ }^{18}$ Ibid
} 


\section{References:-}

\section{Books:-}

1. Erwin, Muhammad. 2015. Hukum Lingkungan dalam Sistem Perlindungan dan Pengelolaan Lingkungan Hidup di Indonesia. Bandung: PT. Refika Aditama

2. Garner Bryan A. 2014. Black's Law Dictionary Tenth Edition, Claitors Pub Division. New York

3. Irwansyah. 2013. Aspek Hukum Audit Lingkungan. Jakarta: YAPMA

4. Mahfud Syahrul. 2012. Penegakan Hukum Lingkungan Indonesia, second edition, First Print. Yogyakarta: Graha Ilmu

5. Peter, Mahmud Marzuki. 2009. Penelitian Hukum, Jakarta: Kencana Prenada Media Group

6. Rahmadi, Fate. 2016. Hukum Lingkungan di Indonesia. Jakarta: PT. Rajagrafindo Persada

7. Soekanto, Soerjono and Sri Mamudji. 2001. Penelitian Hukum Normatif; Suatu Tinjauan Singkat, Jakarta: Raja Grafindo Persada

8. Yunus Wahid. 2014. Pengantar Hukum Lingkungan. Makassar: Arus Timur

\section{Journals:-}

1. Akin, Jena. 2012. Civil Justice in the Mountains: The Bolivian Andes as Grounds for Climate Reform. Colorado Journal of International Environmental Law and Policy, Volume 23 (Online), Number 2 (accessed on January $1^{\text {st }} 2018$ )

2. Career Development Office of Yale Law School. 2017. Environmental Law. Yale Law School Nondiscrimination Policy, (Online), p. 5 (accessed January $1^{\text {st }} 2018$ ).

3. Cinnamon, Carlarne. 2014. Delinking International Environmental Law \& Climate Change. Michigan Journal of Environmental \& Administrative Law, Volume 4 (Online), Issue 1 (accessed January $1^{\text {st }} 2018$ )

4. UN Doc. A / CONF.151 / 26 (Vol. III), United Nations Conference on Environment and Development, Rio de Janeiro, Braz., June 3-14, 1992, Agenda 21, 23.2, (Aug.14, 1992), available athttp://www.un.org/esa/dsd/agenda21/res_agenda21_23.shtml ., accessible date, (accessed January $1^{\text {st }} 2018$ )

5. UN Doc. A / CONF.151 / 26 (Vol. I), United Nations Conference on Environment and Development, Rio de Janeiro, Braz., June 3-14, 1992, Rio Declaration on Environment and Development, 10, (Aug. 12, 1992) [hereinafter Rio Declaration], available at http://www.un.org/documents/ga/conf151/aconf15126lannexl.htm, (accessed January $1^{\text {st }} 2018$ )

Web:-

1. Exception Online, "Gunung Bawakaraeng Experiencing Damage", http://eksepsionline.com/ 2017/05/09/gunung-bawakaraeng-engeng-kerusakan/, (accessed October $10^{\text {th }} 2017$ )

2. WWF, " Deforestation", http://menulis-makalah.blogspot.co.id/2015/06/cara-menulis-footnote-catatan-kakiyang.html, (accessed December $4^{\text {th }}$ 2017). 